30一60公尺。位桥墽工程中可以部分打入上內作为 基础, 部外留露在外作为墽身。在水中架設鑽探架艾 承台时用四根管漛就够了。施工时閏仅需几个星期。

在这部分的报告会上，我們宣讀了“予应力混㠜 土在中国的应用”一文，將我国兩年来在工厂建筑、鉄 路桥染建筑以及水工輸电等建筑方面探用予应力混凝 土.的规模及經济性作了介紹, 並指出予应力混凝士在 我国今后更大规模的建設中的宏偉远景。这个报告頗 引起所有与会者重視, 确在这次国际会議中起了影响 作:汀。

会后，我们环繞鋼称混凝士及予应力泡凝上为中 心，在宗、西柏柇、民主德国及莫斯科进行了一些参 覌, 並与有关学省和工积师們接触。我侧看了：肞先 張法和后張法生产予应力軌枕的工艺、月予应力棈例 造压力水管的工艺、速續自动配的邠的工艺、水池盤絲 張拉工艺、予应力混凝士梁的疲劳强度侙驗、用予制 桿件拼裝的36公尺跨度的屋架、铜笳混凝土抗创性的 研究、耐热混凝土的研究等等。在参覌及和学省們的 接触中我們了解到：大跨度工柴建筑上均探用予应力 混凝士上屋架，而不用銅屋架。居住建筑上探用予应力

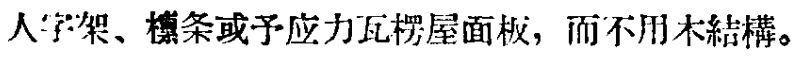
生产浰压强度能达18个大气压的予应水管, 大量替 代了給水工程中的鍓管。应应力油管湖池正在發展。 大力生产予应力混凝土軌枕来伦替木軌枕。大压力机

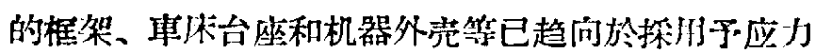
混凝土。耐热混凝土开始用於高溫溶鉄曥 (代替耐火 砧)和弡射火筋的台架 (代替生鉄)，数果及經济性均

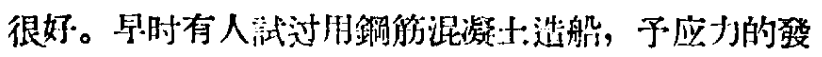
展將更使其有現实意义等等。

关於这次会議的論文和报告的詳細內容可参闃已 刊出的初步諭文篗（此项文件分别保存在建筑科学研

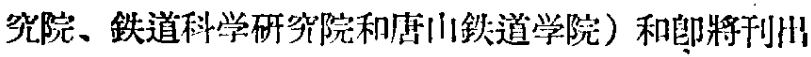
的最后論文集。

朱振德

（建筑工程部建筑科学研究院）

\section{絹紡原料探用压熱脫膠法 研究成功}

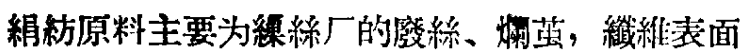
附有絲膠, 需經过除膠手續吉能紡絲。絹紡原料脫 䤅法五十多年来大都探用被醉与化学法, 过程中需时

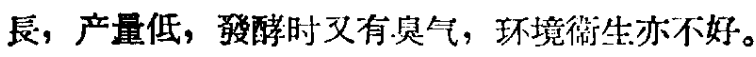

紡織工業部紡織科学院上海分院与国营上海絹紡 「技术人員，研究成功了䊘紡原料的压热脫膠浩。这 是絹紀原料脫膠技术大革命, 为脫膠机械化、自动化 打下良好的基础。

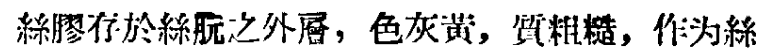
盶之保护与膠結畝。絲膠为多种烡酸組成, 日的分 析至少在 12 种以上, 其經驗式为 $\mathrm{C}_{15} \mathrm{H}_{25} \mathrm{~N}_{5} \mathrm{O}_{8}$, 絲膠 可溶於 $\mathrm{pH} 2.5$ 滕溶液中, 或 $\mathrm{pH} 9.5$ 的醶溶液中。

絲膠不溶於冷水、酒精、乙醚、河酮等溶剂, 溶 於热水, $85^{\circ} \mathrm{C}$ 时絲膠开始膨化, $95^{\circ} \mathrm{C}$ 时开始溶解。 实驗証叮, 在 $112^{\circ} \mathrm{C}$ 至 $119^{\circ} \mathrm{C}$ 的龄溶液中絲膠溶解能 加速, 所以压热脫膠所探取之压力在0.5-1 公斤/体 方公分間, 超过此压力, 絲膯解除速度並不增速。

压热脫膠法应肞於紡 原料的脫膠, 在国外 $\mathrm{I} \Gamma^{-}$

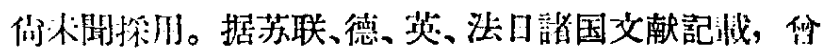

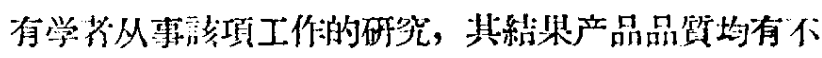
约現像，熶近紡織研究院上海分院与上海絹紡厂找术 人員作了有系統的研研与䳝驗，探用不同原料（包拈

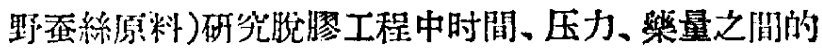
相互关系, 工艺条作确定后, 其成品品䁈均与, 产 量提高, 蒸气节省, 操作者劳动保护得到大大改管。 如以同一种下脚茧, 同一容量之容器, 产量可提高仙 倍, 絲量提高 $20 \%$, 緎維增長 $10 \%$, 蒸气省三倍, 夏季隇低車間中高溫，冬季隇少車間中霧气。

压热朌膠法不但适用於家亘絹䄱原料，亦适用於 柞奛及野亘原料，但其技术条件需随不同原料的品种 作适当改变。

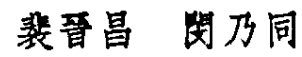

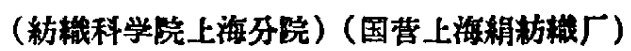

\section{短訊}

\section{尼可拉耶夫敉授关於新模造运动的报告}

苏联第四紀委員会副主席、莫斯科地質勘探学院 尼可拉耶夫教授自 6 月 10 日起在中国科学院作了下 列关於新種造运动和第四紀沉积物研究的一系列学术 报告: (1)研究新構造运动的任务和方法; (2)絆制新 棈造运动圖的原則和方法; (3)欧洲大陆的最新構 造 及其表現的規律; (4)地売發展的新阶段及其对 解 决 大地構造阔題的意义; (5)新構造和地貌; (6)黄士及 其它成因类型的岩不; (7)水工建設中工程地筫跑 探 方法的問題。

尼可拉耶夫教授在报告中对一些有关新權造运动 的基本開題都作了詳尽的論述，他發展了奥勃篔契夫 院士关於新構造运动的学馀, 詳絧地論逝了新構造运 动的定义，明确了新構造运动是第三紀后期开始的構 造运动。对研究新構造运动必須探用綜合的方法, 他

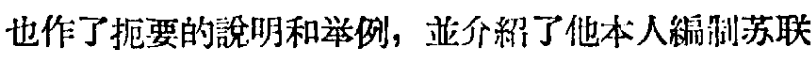
新棈造运动圖和欧亞大陆(包括海洋部分)新構造运动 
圖的殌驗和制圆的方法。

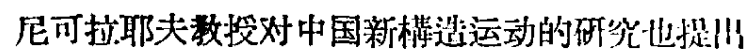

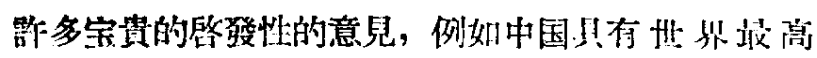

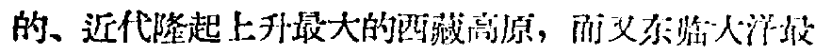

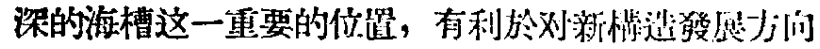
的研究，丁解陆台和地槽䢹的关系。

他也提玨在中国現在正进行訢多大的水工建部， 有些巨大的水麻將形成人工海和人工湖, 对这样䙺棪 巨大的水闲地区进行新構造运动和現代模造运动的研 究和测量以覌祭地党的变化, 不仅冾其科学上的价值,

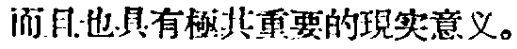

[刘东生]

\section{中共吉林省变角人㬀德等 \\ 手任东北人民大学数授}

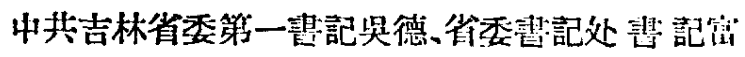
振声、省委文教部長宋振庭和中共長春枋委第一涔: 范

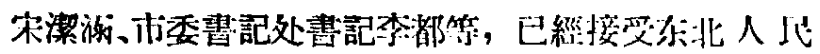
大学的聘書，策任教授。

东北人民大学为了加强理諭联系实际和提高諯瑟

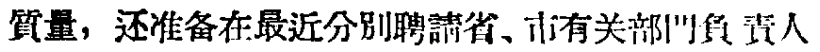
洨学講锞。

\section{天津市科联和科普組織吸收 一批工农会負}

七十名工人和农民技术革新积極分一个和刢造發明 者, 被中华全国自然科学尃临学会联合会天津才分会 和天津市犐学技术显及协会接受为会員。他們分别参 加了电子、造船、机械、电机、金屬、紡織、农等等十四行个 專門学会。

这些会員中有：只上过四年学的新安电机厂錯工 周学仁, 他不迷信書本和軎家, 敢想敢干, 刢造了水

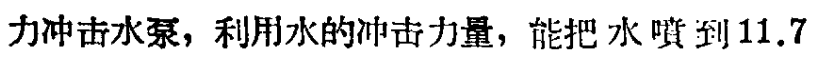

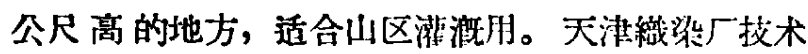
員染树楷刢造了不用染料染絲綢的方法，他最近又同 利和織物公司青年技术員汪宝树研究不用染料染棉織 物成功。中国石油公司天挂採購供应站的計量員郭树

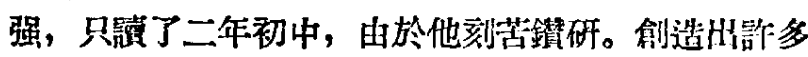
石油計量的方法，使我国石油計量工作有了一夽理 諭。他並写了 “石油計量工作手册” 和 “談政裝石油 产品的計量”兩書。只有初小文化程度的 22 岁农村靑 尔藤藍用, 在农村建成上造自来水厂, 实現了农村领 水大革命。

科联天津分会和天津市科普常委联席会議决定， 今后要不断吸收工农票众中的刢造發明者、技术革命 积極分子，使科学工作能够密娜联系莘众，更好地为
部会主义建誩服务。

\section{朝解科学院通过發展科学十年远景㖕划}

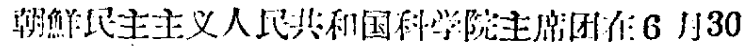

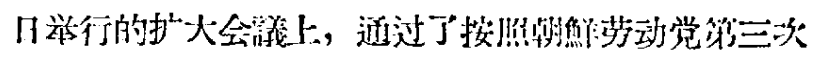

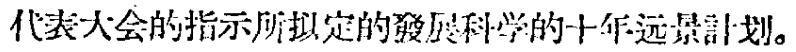

訃划規定, 首先进行目的住於保証优先發展重工

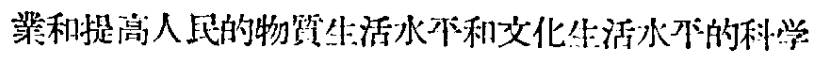

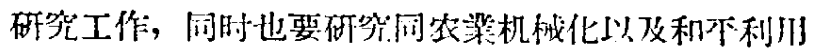

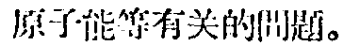

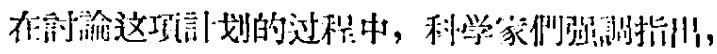

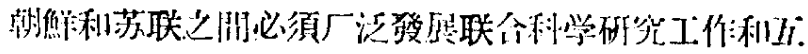
朴艾捠科学资料。

\section{苏联科学院法学研究所举行学术会議}

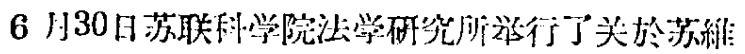

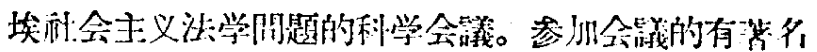

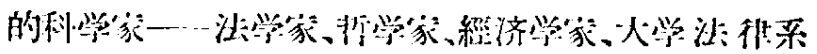

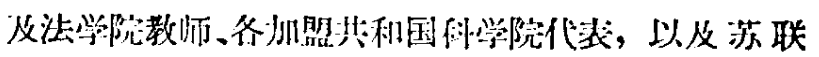

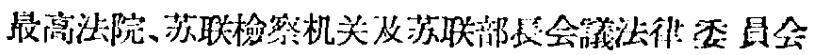

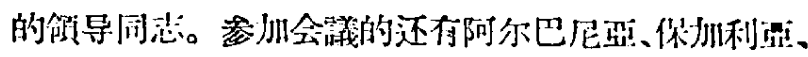

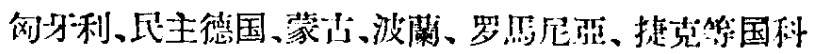
学家。

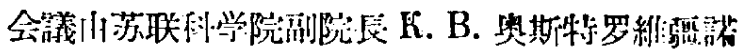

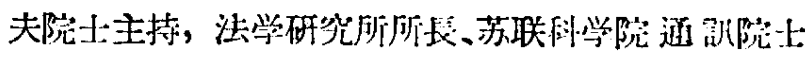

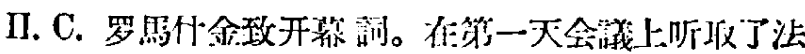
学博士 И. В. 巴们洛夫“关於苏維涘刑会主义的泣制” 的报告和法学缚土 B. M. 奇齐克瓦德扰的“苏联形: 会 主义法律製度”的报告。

\section{“苏联科学院历史”已开始出版}

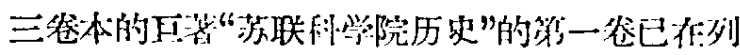

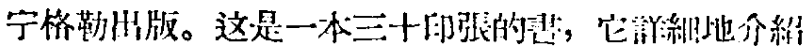

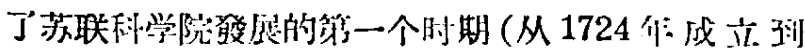
1803作)的历史。

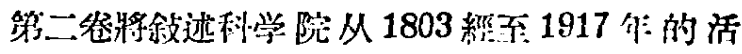

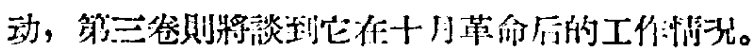

\section{更 正}

本刊 1958 第 9 期 281 面圆 1, 漏排横坐标的訊明: 刀

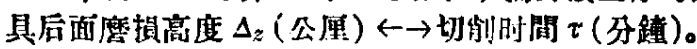

又圖 1 的圖註中“切削时 $\tau$....应为“切例时間 $\tau$...”。 同期 282 面左欄 13 行 “...磨刀的导热性”应为 “...發力 的导热性”。

本刊1958 年第 12 期 379 面表 1 柔皮欄中 2.40 应为

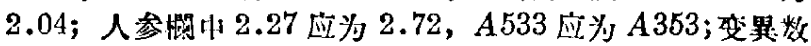
分析註第二行 “学 $P=0.01$ 的”, 应为 “当 $P=0.001$ 时”; 特此更正如上。 